\title{
A Study on the Effects of Stress of Pain and Ethanol on the Reproductive Function and Beta-endorphin Release in Mature Female Albino Rats and Their Offspring
}

\author{
Romysa A. El-Sherbeny and Mohamed N. Abdel Rahman \\ Department of Physiology and Pharmacology, \\ Faculty of Medicine, Tanta University
}

\begin{abstract}
The present work was performed to investigate the effect of acute and chronic stress of pain and ethanol on the reproductive function, hormonal response and $\beta$ endorphin release in non pregnant, and pregnant female albino rats and their offspring. This study was performed on 60 mature female albino rats divided into two groups, non pregnant group and pregnant group, each group is subdivided into 3 groups: 1 Control group 2-Acute stress group in which the rats were exposed to stress of pain for one hour or ethanol injection 3-Chronic group in which the rats were exposed to stress of pain for one hour or ethanol injection daily for one week. The pregnant group was subdivided in the same manner into three groups, and the resulted neonates were divided according their mothers into three groups. At the end of experiment, the normal rats and neonates of pregnant rats were decapitated, and blood samples were collected. The pregnant rat's blood was collected from retro orbital plexus. Then serum was separated and used for determination of serum progesterone, estrogen, follicle stimulating hormone (FSH), Luteinizing hormone $(L H)$, serotonin and $\beta$ endorphin levels. Tissue samples were taken from normal group by opening of the abdominal cavity. Ovaries, ovarian ducts and uterus were excised for histological examination. The results revealed significant increase in progesterone, estrogen, LH, FSH and serotonin, and significant reduction in $\beta$ endorphin levels in acute non pregnant and pregnant groups. The chronic pregnant and non pregnant groups showed, significant reduction in progesterone, estrogen and LH and significant increase in FSH, serotonin and $\beta$ endorphin levels.. $\beta$ endorphin of neonates showed significant reduction in neonates of rats exposed to chronic ethanol injection and significant increase in neonates of rats exposed to chronic pain. Histological examination showed reduction of uterine vascularity, leucocytes infiltration, in rats exposed to acute stress of pain and ethanol injection. The chronic groups showed dilated uterine lumen, increased uterine vascularity, leucocytes infiltration and increased viable corpora lutea. It is concluded that the application of stress of pain or injection of ethanol to female albino rats caused disturbance of reproductive function. Also, ethanol injection to pregnant rats caused suppression in $\beta$ endorphin release in their offspring, which may be due to apoptotic death of neurons secreting $\beta$ endorphin.
\end{abstract}




\section{INTRODUCTION}

The Arabic physician Avicenna (Ibn Seina) considered pain as an unnatural condition to which the body is labile ${ }^{(1)}$. Pain is considered as strong stress as well as protector of the living body ${ }^{(2)}$. Pain receptors are sensitive to wide range of stimuli such as thermal, mechanical and chemical stimuli. In contrast to other receptors in the body, pain receptors adapt very little, and excitation of pain fibers become progressively greater as the pain stimulus continues especially in case of slow aching pain ${ }^{(3)}$. Acute pain is that pain that is temporarily related to injury and resolves during the appropriate healing period, and chronic pain, is that type of pain which persists for more than three months ${ }^{(4)}$. Stress is considered as the situation when that hypothalmopituitary adrenocortical axis represented mainly by elevated ACTH levels, which causes increase of plasma cortisol $^{(5)}$. Adrenergic stimulation elevates plasma epinephrine levels ${ }^{(\mathbf{6})}$, and serotonergic system is considered as neuromodulatory system interacting with other neurotransmitters in the brain. The central serotonergic receptor occur presynaptically to mediate inhibition of adrenaline ${ }^{(7)}$. Goldstien $^{(8)}$ defined stress, as a condition of discrepancy between what is observed or sensed, and what is expected as a compensatory response. There is a direct relationship between stress and disorders such as heart diseases, increase incidence to infection and psychological problem $^{(8)}$. A stressor may be any stimulus that disrupts homeostasis, which may be physical, chemical psychological, social and physiological $^{(9)}$. Among the physical causes of stress, pain comes as an important cause to produce physical, sensory, astronomic, behavioral and neuroendocrinal responses ${ }^{(\mathbf{1 0})}$. Stressors may be divided into acute and chronic and many stressors differ in their intensities into severe, moderate and mild ${ }^{(\mathbf{1 0})}$.

Ethanol consumption during pregnancy is a significant public health problem and results in a wide range of adverse outcomes for the child. Many of fetal ethanol exposed children show deficit in cognitive and behavioral functions including hyperactivity and poor stress tolerance ${ }^{(11)}$. In animals, behavioral and neurochemical studies indicated that, the defect in the ability of the animals to respond appropriately to stress appears to be due to alterations in the function of the hypothalamopituitary adrenal axis ${ }^{(12)}$. Animals exposed to ethanol during prenatal period are typically hyper responsive to stressors and drugs during adulthood and show increased corticosterone $^{(\mathbf{1 3})}$. The aim of the present work was to study the effect of stress of pain and ethanol injection on the reproductive function, serotonin and $\beta$ endorphin release in normal non pregnant and pregnant female albino rats and their offspring.

\section{MATERIALS \& METHODS}

60 mature female albino rats were checked for their estrus cycles and for pregnancy with average weight of 
200-275gm. They were kept at comfortable room temperature and have been fed bread and milk diet with free water access. They were kept away from any possible cause of stress such as noise. Wide space was allowed for each rat. The rats were divided into 2 groups:

1- Non pregnant mature albino rats: composed of 30 rats and subdivided into 3 groups:

Group (1): control group, composed of six rats.

Group (2): acute stress group, composed of 12 rats, subdivided into:

6 rats were exposed to stress of pain for one hour.

6 rats were injected intraperitonealy by ethanol $11.34 \%$ in a dose of 2.5 $\mathrm{gm} / \mathrm{kg}$ body weight ${ }^{(14)}$.

Group (3): chronic pain group: this group was composed of 12 rats, subdivided into:

6 rats were exposed to stress of pain for one hour daily for one week.

6 rats were injected intraperitonealy by ethanol in a dose of $2.5 \mathrm{gm} / \mathrm{kg} \mathrm{BW}$ daily for one week

2-Pregnant rats: composed of 30 rats and subdivided into 3 groups:

Group (1): control pregnant Group: composed of six rats.

Group (2): acute stress pregnant group: composed of 12 rats, subdivided into

6 rats were exposed to stress of pain for one hour.

6 rats were administrated by ethanol intraperitonealy in a dose of $2.5 \mathrm{gm} / \mathrm{kg}$ BW.

Group (3): chronic stress pregnant group which composed of 12 rats, subdivided into

6 rats were exposed to stress of pain for one hour daily for one week.
6 rats were administrated by ethanol intraperitonealy in a dose of 2.5 $\mathrm{gm} / \mathrm{kg} \mathrm{BW}$, daily for one week.

The offspring groups: composed of 30 neonates and were divided according to their mothers into 3 groups:

Group (1): Control group which composed of 6 neonates from the control rats.

Group (2): The neonates of rats exposed to acute stress, composed of 12 neonates and subdivided into:

6 Neonates from the rats exposed to acute stress of pain for one hour.

6 Neonates of rats injected by ethanol.

Group (3): The neonates of rats exposed to chronic stress for one week, composed of 12 neonates and subdivided into

6 Neonates of rats exposed to stress of pain one hour daily for one week.

6 Neonates of rats injected by ethanol daily for one week.

The apparatus used for induction of pain was based on the modified method of Grant ${ }^{(15)}$. It is a wooden box with dimension of $50 \times 30 \times 40$ $\mathrm{cm}$. the floor of the box was made of grid of parallel rods of about $2 \mathrm{~mm}$ in diameter and $4 \mathrm{~mm}$ apart. The rods were connected to electrodes of a stimulator through which electric shocks (painful stimuli) were released to the rods of the floor. Electric shocks of 25 volts intensity (galvanic current), 25 pulses/second according to the method of Odio and Brodish (16). The current was applied for 10 seconds with an interval of rest for 10 seconds and this process is continued for one hour ${ }^{(17)}$.

At the end of the test period, the non pregnant groups were decapitated and blood samples were collected. 
Blood samples from pregnant groups were taken from retro orbital plexus, and their neonates were decapitated and blood samples were collected .Serum was separated for hormonal assay of the following hormones

1-Serum estrogen was measured according to the method of Ismail et al., ${ }^{(18)}$.

2-Serum progesterone was measured according to the method of Ismail et al., ${ }^{(18)}$.

3-Serum LH was measured according to the method of Kulin and Antner (19)

4-Serum FSH was measured according to the method of Santner (19)

5-Serum $\beta$ endorphin was measured by the method of Lebelt et al., (20).

6-Serum serotonin (5-HT) by ELISA method using IBL kits according to the method of Kruglikov ${ }^{(21)}$.

Vaginal smears:

Estrous cycle examination: A dropper was used, drop of water put into the vagina of each female albino rat then was withdrawn again. The contents were spread over a clean glass slide to determine the different cell patterns. This procedure was repeated every day before and after the application of pain and once for the control group ${ }^{(22)}$.

Tissue samples:

Were taken from rats exposed to acute and chronic pain, and also from acute ethanol injected rats. At the end of experimental period, the abdominal cavity was opened. Ovaries, ovarian ducts and uterus were excised. Tissue samples were kept in formalin solution $(10 \%)$. Paraffin blocks were made for the tissue samples. Slides were stained by haematoxylin and eosin.

Statistical analysis:

All results were expressed as mean values+ (SD) standard deviation. Mean values of the different groups were compared using one way analysis of variance (ANOVA). The least significant different mean value $<0.05$ was accepted to denote significance.

\section{RESULTS}

1-Non pregnant mature albino rats:

The results of the present work showed that, the acute stress of pain or ethanol injection resulted in significant increase in serum progesterone, estrogen, LH, FSH and serotonin levels and significant reduction in $\beta$ endorphin in relation to control group, $\mathrm{P}<0.05$. Also, chronic stress of pain or ethanol injection showed, significant reduction in serum progesterone, estrogen and $\mathrm{LH}$ levels and significant increase in serum FSH, serotonin and $\beta$ endorphin in relation to control group, $\mathrm{P}<0.05$. The results showed significant increase in $\beta$ endorphin, FSH and serotonin levels in chronic ethanol injection in relation to chronic pain exposure, $\mathrm{P}<0.05$ (Table1).

2-Pregnant albino rats and their offspring:

The results showed significant increase in serum progesterone, estrogen, LH, FSH, serotonin and significant reduction in $\beta$ endorphin levels in groups exposed to acute stress of pain or ethanol injection in relation to control, $\mathrm{P}<0.05$. Significant reduction in serum progesterone, estrogen, LH levels and significant 
increase in $\mathrm{FSH}$, serotonin and $\beta$ endorphin in groups exposed chronic pain and ethanol injection in relation to control, $\mathrm{P}<0.05$. Their was a significant increase in FSH levels in rats injected by ethanol in relation to those exposed to acute stress of pain, $(\mathrm{P}<0.05)$.

\section{$\beta$ endorphin levels of the neonates:}

The results showed significant increase in serum $\beta$ endorphin level in neonates of rats exposed to chronic stress of pain, and significant reduction in neonates of rats exposed to chronic ethanol injection in relation to control, $(\mathrm{P}<0.05)$, (Table2).

\section{Histological picture:}

Non pregnant rat exposed to acute stress of pain showed average uterine lumen, fig.(1).The ethanol injected rats showed slightly dilated uterine lumen, fig.(2) while the uterine vascularity decreased with leucocytic infiltration. The non pregnant rats exposed to chronic stress of pain showed dilated uterine lumen, fig (3) and the dilatation is more obvious in ethanol injected rats fig (4). There were leucocytic infiltration and increased uterine stromal cellularity fig. (5\&6). Corpora leuitea were visible and regressive, fig (7).

Vaginal smears:

Control group showed normal cycling pattern. Each cycle ranged between four and five days and consisted of four phases. In the destructive phase there were predominating leucocytes and considerable amount of epithelial cells and mucus. In the estrous phase only cornified cells could be seen. In the metoestrous phase a mixture of epithelial cells, leucocytes and some mucus were seen. Acute and chronic exposure to stress of pain or ethanol injection, showed irregular cycling pattern with non specific cytological picture of vaginal smear. Most films of vaginal smear showed a spreading pattern of all elements, epithelial cells, leucocytes and mucous.

Table (1): Effects of stress of pain and ethanol injection on the progesterone, estrogen, LH, FSH, serotonin and $\beta$ endorphin levels of the mature non pregnant albino rats (mean $6 \pm \mathrm{SD}$ )

\begin{tabular}{|l|l|l|l|l|l|}
\hline \multirow{2}{*}{ Parameter } & \multirow{2}{*}{ Control } & \multicolumn{2}{|l|}{ Acute stress } & \multicolumn{2}{l|}{ Chronic stress } \\
\cline { 3 - 6 } & & Pain & Ethanol & Pain & ethanol \\
\hline $\begin{array}{l}\text { Progesterone } \\
(\mathrm{mg} / \mathrm{ml})(\mathrm{n}: 6)\end{array}$ & $45.6+2.58$ & $50.5+2.94^{*}$ & $51+2.82^{*}$ & $8.2+0.57^{*}$ & $8.6+0.62^{*}$ \\
\hline $\begin{array}{l}\text { Estrogen }(\mathrm{pg} / \mathrm{ml}) \\
(\mathrm{n}=6)\end{array}$ & $73.5+1.87$ & $79.8+2.63^{*}$ & $80+3.74^{*}$ & $10.5+1.87^{*}$ & $12.5+1.87^{*}$ \\
\hline LH (I.U) $(\mathrm{n}=6)$ & $0.577+0.008$ & $0.606+0.01^{*}$ & $0.621+0.01^{*}$ & $0.454+0.01^{*}$ & $0.452+0.007^{*}$ \\
\hline FSH (I.U) (n=6) & $0.467+0.007$ & $0.524+0.006^{*}$ & $0.531+0.007^{*}$ & $0.579+0.008^{*}$ & $0.586+6.006^{*}$ \\
\hline $\begin{array}{l}\text { Serotonin } \\
\text { nmol/L (n=6) }\end{array}$ & $0.16+0.02$ & $0.24+0.02^{*}$ & $0.26+0.02^{*}$ & $0.34+0.01^{*}$ & $0.36+0.01^{*}$ \\
\hline $\begin{array}{l}\text { ß endorphin } \\
(\mathrm{pmol} / \mathrm{L})(\mathrm{n}=6)\end{array}$ & $11.06+0.22$ & $9.07+0.15^{*}$ & $9.43+0.14^{*}$ & $40.86+1.0^{*}$ & $41.76+0.71^{*}$ \\
\hline
\end{tabular}


Table (2): Effects of stress of pain and ethanol injection on the serum progesterone, estrogen, LH, FSH, serotonin and $\beta$ endorphin levels of the pregnant albino rats and their offspring (mean $6+\mathrm{SD}$ )

\begin{tabular}{|l|l|l|l|l|l|}
\hline \multirow{2}{*}{ Parameter } & \multirow{2}{*}{ Control } & \multicolumn{2}{|l|}{ Acute stress } & \multicolumn{2}{l|}{ Chronic stress } \\
\cline { 3 - 6 } & & Pain & Ethanol & Pain & ethanol \\
\hline $\begin{array}{l}\text { Progesterone } \\
(\mathrm{mg} / \mathrm{ml})\end{array}$ & $337.6+11.4$ & $418.6+12.3$ & $421.6+10.5^{*}$ & $56.1+4.6^{*}$ & $61.6+3.98^{*}$ \\
\hline Estrogen $(\mathrm{pg} / \mathrm{ml})$ & $438+44.8$ & $512.3+56.7^{*}$ & $519+53.09^{*}$ & $165.1+10.6^{*}$ & $172.1+6.8^{*}$ \\
\hline LH (I.U) & $4.57+0.07$ & $4.79+0.07^{*}$ & $4.86+0.08^{*}$ & $3.34+0.05^{*}$ & $3.31+0.04^{*}$ \\
\hline FSH (I.U) & $0.946+0.009$ & $1.394+0.06^{*}$ & $1.504+0.04^{*}$ & $1.613+0.04^{*}$ & $1.637+0.04^{*}$ \\
\hline Serotonin nmol/L & $0.47+0.03$ & $0.6+0.02^{*}$ & $0.61+0.03^{*}$ & $0.74+0.06^{*}$ & $0.76+0.04^{*}$ \\
\hline ß endorphin (pmol/L) & $18.06+0.9$ & $15.9+0.67^{*}$ & $16.3+0.67$ & $80.7+4.2^{*}$ & $82.1+5.5^{*}$ \\
\hline $\begin{array}{l}\text { ß endorphin of the } \\
\text { offspring (pmo/L) }\end{array}$ & $9.61+0.67$ & $9.08+0.57$ & $9.01+0.41$ & $30+1.63$ & $1.65+0.43^{*}$ \\
\hline
\end{tabular}

*:Denotes statistical significance.

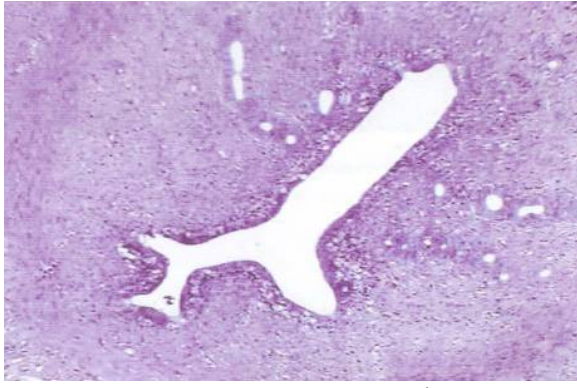

Fig. (1): Rat uterus exposed to acute stress of pain, showing average slit shaped uterine lumen, decreased uterine vascularity and leucocytic infiltration $(40 \% \mathrm{x})$.

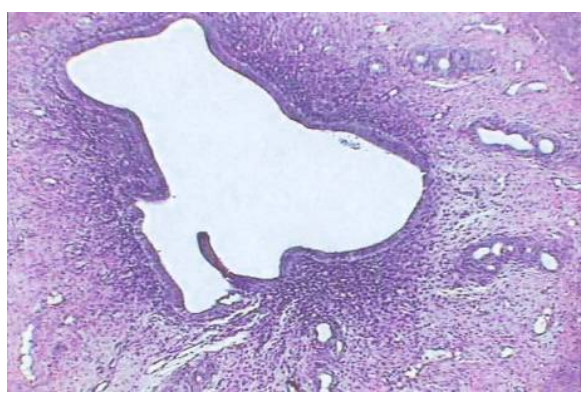

Fig. (3): Rat uterus exposed to chronic stress of pain showing dilated uterine lumen, increased uterine vascularity, leucocytic infiltration $(40 \% \mathrm{x})$.

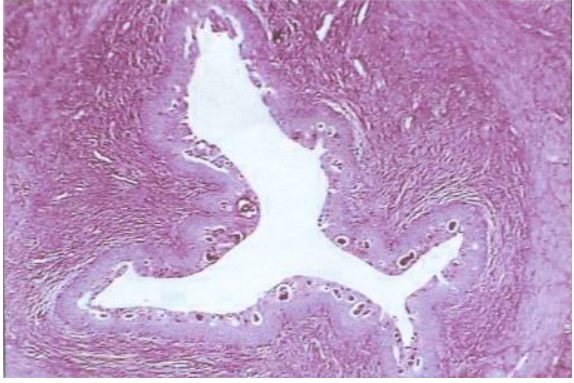

Fig. (2): Rat uterus exposed to ethanol injection, showing slightly dilated slit shaped uterine lumen, decreased uterine vascularity and leucocytic infiltration $(40 \% \mathrm{x})$.

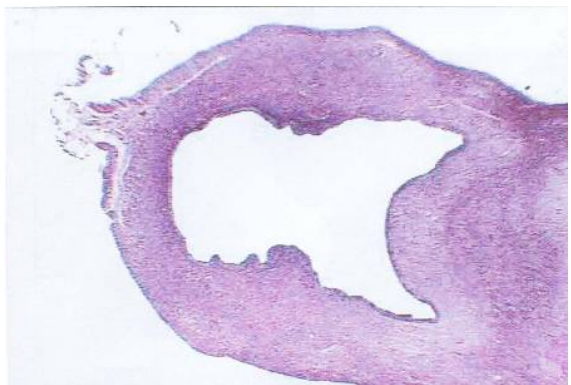

Fig. (4): Rat uterus exposed to chronic injection of ethanol showing dilated lumen $(40 \% \mathrm{x})$. 


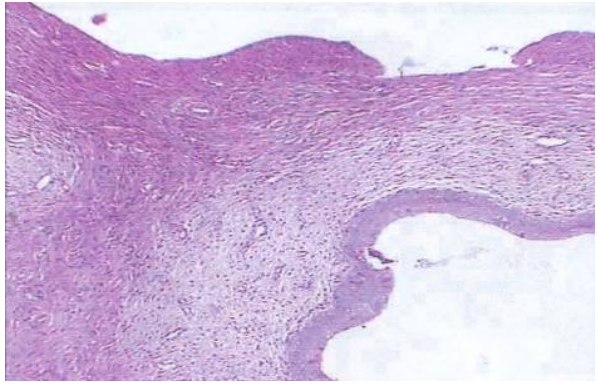

Fig. (5): Rat uterus exposed to chronic injection of ethanol showing increased leucocytic infiltration $(40 \% \mathrm{x})$.

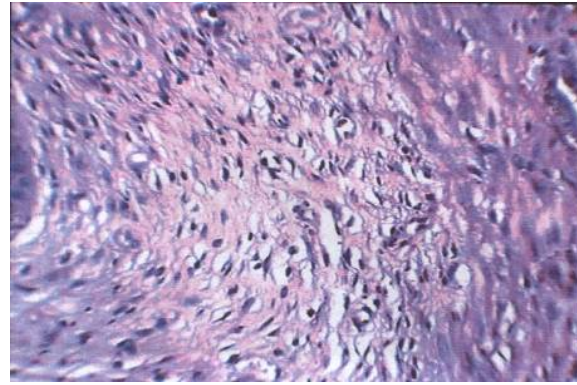

Fig. (6): Rat uterus exposed to chronic stress of pain showing increased leucocytic infiltration $(100 \% \mathrm{x})$.

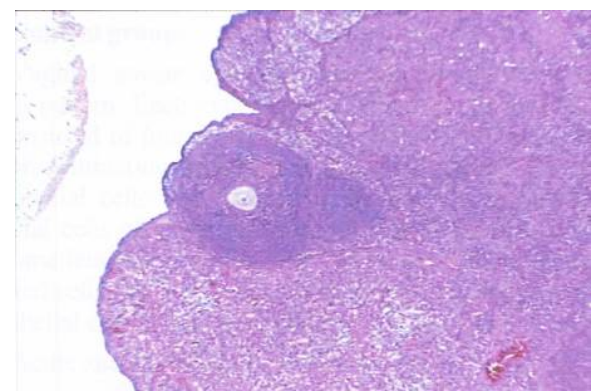

Fig. (7): Rat uterus exposed to chronic stress of pain showing growing follicle, visible and regressive corpora lutea.

\section{DISCUSSION}

Pain is not simply an unpleasant sensation as the international association of the study of pain IASP defined it ${ }^{(23)}$. Cognition is involved in the formulation of pain perception leading to many emotional consequences and behavioral responses that greatly affect homeostasis, ${ }^{(24)}$ which can explain the stressful effect of pain. The nerve fibers that carry pain sensation were found to end non-specifically at the level of the reticular formation. From there, another sets of neural connections flow to reach different centers as the hypothalamus ${ }^{(25)}$. Among different stressors, pain may be considered as a physical or emotional cause of stress, and its nervous pathway reach nearly all vital brain centers away from pain pathway through hypothalmo-pituitary adrenal $\operatorname{axis}^{(26)}$.

The electric shocks were found to be more suitable in applying both acute and chronic pain, as electricity gives an adjustable and simple way to induce pain ${ }^{(27)}$. The results showed significant increase in serum levels of progesterone and estrogen and reduction in $\beta$ endorphin level in rats 
exposed to stress of acute pain. Such increase in progesterone may be explained by the first and the second phases of the general adaptation syndrome $^{(28)}$, which described that, the organism recognizes the threat and push different body systems by activating the hypothalmo-pituitarygonadal axis ${ }^{(29)}$, Moreover the reduction in $\beta$ endorphin release, which was supported by the negative correlation between estrogen and $\beta$ endorphin and positive correlation between gonadotrophins and $\beta$ endorphin ${ }^{(30)}$.

The rats exposed to stress of chronic pain showed decrease in both estrogen, progesterone and LH levels. It was noticed that the pattern of relationship between gonadotrophins (FSH \& LH) and related sex hormones (estrogen \& progesterone) had been reversed i.e. while the FSH level was higher than the control groups values, the estrogen dropped. On the other hand, although both LH and progesterone levels decreased, and drop of progesterone level not related to that of LH. This can be explained by the third phase of general adaptation syndrome (exhaustion phase) when the organism fails to cope with the stressor, and its body systems begin to shutdown, and fail to perform their expected function, which may be due to increased release of $\beta$ endorphin ${ }^{(31)}$.

Ethanol results in significant increase in estrogen, progesterone and $\beta$ endorphin in acute group injected by ethanol, but there were significant reduction in estrogen and progesterone and significant increase in $\beta$ endorphin levels in chronic ethanol group. This may be due to increase secretion of corticosterone. The increased hormonal response to injected ethanol, ${ }^{(\mathbf{1 3})}$ may be due to stimulation of hypothalamo-pituitary adrenal axis ${ }^{(32)}$. The significant reduction of $\beta$ endorphin in acute pain or ethanol injection, may be due to an abnormal production and release of corticotrophin releasing hormone following stress challenge, and altered stress regulation process ${ }^{(31)}$. Stress causes activation of corticotrophin releasing hormone. The neuronal function is controlled by extrahypothalamic and hypothalamic inputs involving several neurotransmitters and their receptors $^{(\mathbf{2 6})}$. However, there is a significant inhibitory role of hypothalamic $\beta$ endorphin neurons on corticotrophin releasing hormone ${ }^{(\mathbf{1 3})}$. Also the neurotoxic action of ethanol on developing $\beta$ endorphin neurons (12), which may be due to, increase $\beta$ endorphin neuronal death during the developmental period. The mechanism may be due to suppression of cyclic adenosine monophosphate production, and activation of transforming growth factor $\beta 1$-linked apoptotic signaling $^{(\mathbf{1 4 , 3 2})}$.

The increase in serotonin level in acute and chronic groups, could be explained by that, the hypothalamus regulates the physiological response to stress through the sympatho-adrenal axis composed of the adrenal medulla and sympathetic nervous system. Also the hypothalamo-pituitary-adrenal axis, releases a number of factors that control the function of other endocrine glands ${ }^{(\mathbf{3 3})}$. Among these factors is $\beta$ endorphin, which is one of the factors that involved in the amelioration of pain ${ }^{(34)}$. Moreover, during stress, $\beta$ 
endorphin and 5-HT are released to participate in the adapted response of the brain to external stimuli. In addition, endogenous opioid peptides that stimulates 5-HT release from the nervous system are centrally acting ${ }^{(35)}$. Also the increase in blood 5-HT in chronic stress, was explained by that, all opioid receptors could inhibit 5-HT release only at high concentration (sever pain), while chronic pain revises little amounts due to adaptation of the receptors ${ }^{(35)}$. Serotonergic receptors occur presynaptically to mediate inhibition of release of both adrenaline and 5HT, also mediate post-synaptic excitation and inhibition of the central nervous system $^{(7)}$.

Histological changes may be attributed to the powerful secretory action of progesterone on the uterine stroma in acute pain group, and reduction of uterine vascularity in chronic pain group, while estrogen and progesterone decreased indicating that there were dissociation between structural changes and their hormonal control, which is one of the stress effects of homeostasis ${ }^{(36)}$. The leucocytic infiltration, is explained by immune system response to potential tissue damage, which initially caused stimulation then depression of the immune system response ${ }^{(37)}$.

The histological picture of the ovary may be due to increased FSH levels, which explained by the presence of many growing follicles. On the other hand the drop of $\mathrm{LH}$ levels may explain the decrease in the viability of the corpora leutea and in turn the decrease in the progesterone levels. These results are supported by the fact that stress suppresses $\mathrm{LH}$ surge due to the stress-induced increase in the release of corticotrophin releasing hormone, which has a direct inhibitory effect on LH release.

\section{Conclusion}

It is concluded that acute and chronic stress of pain or ethanol disturbed the normal reproductive functions. Chronic ethanol administration to pregnant rats caused suppression in $\beta$ endorphin release in their neonates, which may be due to $\beta$ endorphin neuronal death during developmental period.

\section{Acknowledgement:}

Great thanks to doctor Karima Eldesoky professor of pathology for her help in the histological part of this work.

\section{REFERENCE}

1- El-Ansary MS (1987): The concept of pain by Galen versus Avicenna (Review article). J. ESMP 5(1): 1-10.

2- Merskey H (1986): Regional pain a rarely hysterical. Arch. Neurol. 45; $951-918$.

3- Good MD, Brodwin PE, Cood BJ and Kleinuman A (1994): Pain as human experience. An anthropological perceptive. Pbl. University of California Press. PP 158.

4- Conner L (1995): Pain assessment by nurses and nurses notes on it in early acute myocardial infarction. Intensive Crit. Care Nurs. 11: 183 191.

5- Pacak K, Palkovits M, Yadid G, Kvetnansky R, Kopin IJ and Goldstein DS (1998): Heterogonous neurochemical responses to different stressors, a 
test of Slyer S doctrine of nonspecificity. Am J physiol. 275: $r$ 1247 - R 1255.

6- Berne BM and levy $M$ (1998): Integration of the response to stress. Physiology, 2nd ed. Hoffmann press. Mosby Inc. PP 960- 962.

7- Grimaldi B (1999): 5-HT moduline a novel endogenous peptide involved in the control of anxiety. Neuroscience. 93(4): 12231225.

8- Goldstein DS (1995): Stress, catecholamine and cardiovascular disease. Biol. Med. J. 311: 1480 1591.

9- Moberg CP and Mench GA (2000): In the biology of animal stress: basic principle and implication for animal welfare. Pbl. CABI publishing. New York. Chap 3. P. 37.

10- Ursin $H$ and Murison CCR (1984): Types of stress. In: Neuroendocrinalogy and psychiatric disorders ( $3^{\text {rd }}$ edition) Pbl. Raven Press, New York. Chap 3, PP 100.

11- Abel E (2004): Paternal contribution to fetal alcohol syndrome. Addict. Biol. 9: 127133.

12- Zhang $X$, Slivowska JH and Weinberg J (2005): Prenatal alcohol exposure and fetal programming: effects on neuroendocrine and immune function. Exp. Biol. Med. (Maywood) 230: 376-388.

13- Lee S, Sclmidt D, Trlders $F$ and Rivier C (2000): Increased activity of hypothalamic pituitary adrenal axis of rats exposed to alcohol in utero: role of altered pituitary and hypothalamic function. Mol. Cell Neurosci. Ib: 515-528.
14- Sarkar DK, Kuhn P, Marano J, Chen $C$ and Boyadjieva N (2007): Alcohol exposure during the developmental period induce betaendorphin neuronal death. Endocrinol. 148(6): 2828 - 2834.

15- Grant DX (1964): Classical operant conditioning. In: Categories of human learning. Pbl. New York. Academic pres. Chap2, P. 20.

16- Odio MR and Brodish A (1988): Effect of age on metabolic responses to acute and chronic stress. Am. J. Physiol. 254 (17) E 617 - E 624.

17- Swenson RM and Vogel WH (1983): Effect of electric shocks on behavior of rats pharmacol. Biochem. Behav. 18 (5): 689.

18- Ismail AA, Stley B, Burr WA, Cawood M, Short F, Wakelin K and Wheeler $M$ (1986): The quantitative measurement of estrogen, progesterone and testosterone in serum. Am. Clin. Biochem. 23; 113 - 134.

19- Kulin HE and Santner S (1986): The assessment of diminished testicular function in boys of pubertal age. Clin. Endocrinol (OXF) 25(3): 283 - 292.

20- Lebelt D, Zanella AJ and Unshelem J (1998): Physiological correlates associated with cribbing behavior in horses: changes in thermal threshold, heart rate, plasma beta- endorphin and serotonin. Equine Vet J. Suppl. (27): $21-27$.

21- Kruglikov R (1990): 5-HT excess in brain modifies the effect of Bendorphin on learning and memory. ZH Vetch. Nerv Deiat Im Paviova. 40(2): $310-317$.

22- Neubert DH, Marker $J$ and Kwasgroch TE (1977): Controlled breading of lab animals. In: 
Methods in prenatal Toxicology. Pbl. George Theme Stuttgart. PP. 78.

23- IASP (1986): Classification of chronic pain. Pain Suppl. 3: S1 - S 226.

24- Van Luijtelaar E, Budziszewsk B, Jaworska-Feill, Eillis J, Coenen $A$ and Lason W (2000): The Ovarian cycle in rats: a long term EEG study. In: The WAG/Rij rat model of absence epilepsy. Nijmegen University Press. Pbl. The Nijmegen. Moscow research. Pp61 - 70.

25- Price DD (1999): Psychological mechanisms of pain and analgesia. Pbl IASP press Seattle. P 211.

26- Cullinan WE (2003): Central mechanisms of stress integration: hierarchical circuitry controlling hypothalmo - pituitary adrenocortical responsiveness. Front Neuroendorinol 24: $151-80$.

27- Soulsby L and Morton D (2001): Pain: its nature and management in man and animals. Pbl Royal Society of Medicine. Press London - PP 73.

28- Claudia R, Bandler $\mathbf{R}$ and Keay A (2003): A subpopulation of rats show social and sleep-waking changes typical of chronic neuropathic pain following peripheral nerve injury. European J of Neurosci. 17(9): 1907 - 1908.

29- Rutherford KM (2002): Assessing pain in animals. Animal welfare. 11: $31-33$.

30- Sakharkar AJ, Singru PS, Mazumdar $M$ and Subhedar $N$ (2006): Reproduction phase-related expression of beta-endorphin like immunoreactivity in the nucleus Lateralis tuberis of the female Indian major carp: Cirrhinus mrigala; Correlation with the luteinizing hormone cell-ovary axis. J Neuroendocrinol. 18(5): 319-329.

31- Hahn JD, Kalamatianos $T$ and Coen CV (2003): Studies on the neuroanatomical basis for stressinduced estrogen potentiated suppression of reproductive function: evidence against direct corticotrophin-releasing hormone projection to the vicinity of luteinzing hormone releasing hormone cell bodies in female rat. J. Neuroendocrinol. 15(8): 732 742.

32- Chen CP, Kuhn P, Chaturvedi K, Boyadjieva NI and Sarkar DK (2006): Ethanol induces apoptotic death of developing B-endorphin neurons via suppression of cyclic adenosine monophosphate production and activation of transforming growth factor $\mathrm{B}_{1^{-}}$ Linked apoptotic signaling. Molecular pharmacology, 69: 706717.

33- Fredrick J, MaisPand Levine $\mathbf{J}$ (2000): Endogenous opioid suppress activation of nociceptors. Br J of Pharmacol. 133: 23-28.

34- Kabirullah $L$ and Nigal $M$ (2000): Blockade of opioid receptors revealed the hyperalgesic effect of orphanin/ nociceptin in rat hot plate test. $\mathrm{Br} \mathrm{J}$ of Pharmacol. 131: 1647-1688.

35- Monroc P, Kradel B and Smith D (1995): Opioid effects on spinal 5HT release are not related to their antinociceptive action. Eur J Pharmacol. 27(1): 51- 56.

36- Andrei G (1995): Realization of estradiol effects in the uterus of ovariectomised rats under acute stress. Eur. J of Obstetrics \& Gynecology and Reproductive Biol. 70(1): $\quad 69-74$. 


\section{7- Zhang L, Xiao $E$ and Ferin $M$}

(1995): A 5-day estradiol therapy in amounts reproducing concentrations of the early mid follicular phase, prevents the activation of hypothalmo-pituitary adrenal axis by Interleukin-1 alpha in the ovariectomised rhesus monkey. J. Neuroendocrinol. 7: $387-392$.

\title{
تأثثير الإجهاد بسبب الألم و الأيثانول على الوظائف التناسلية وإفراز

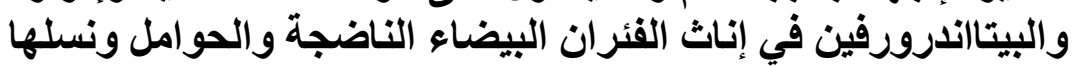

\author{
رومبياء على الثربينى ومحمد نبيه عبد الرحمن \\ قسم الفسيولوجيا و الفارماكولوجيا- كلية الطب ـ - جامعة طنطا \\ يهرف هذا البحث إلى دراسة تأثثير الإجهاد بسبب الألم والأيثانول ودر اسة تأثثر اه على الجهاز التناسلي في إناث

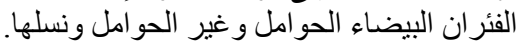

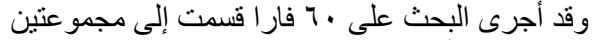

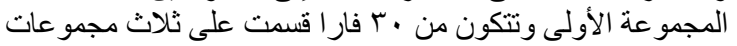

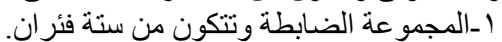

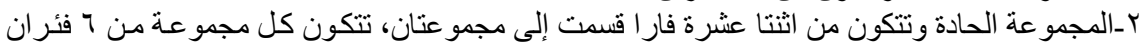

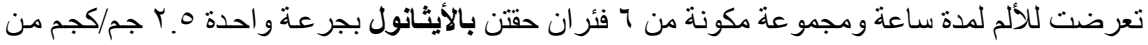

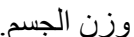

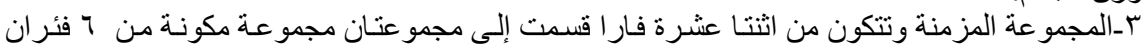

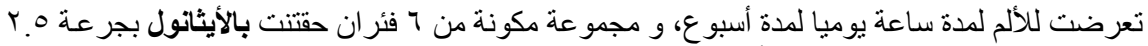

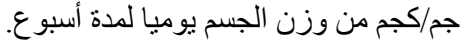

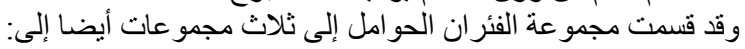

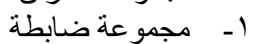

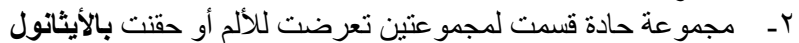

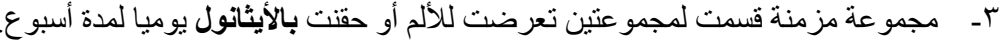

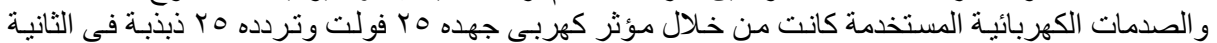

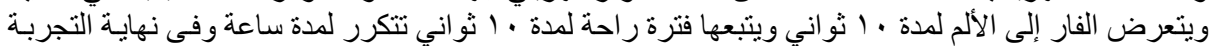

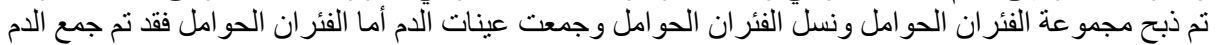

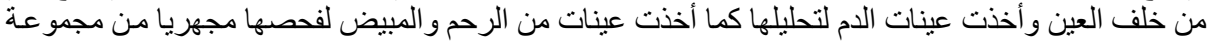
غير الحوامل.

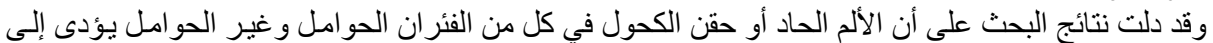

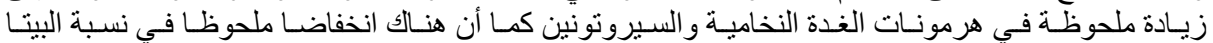

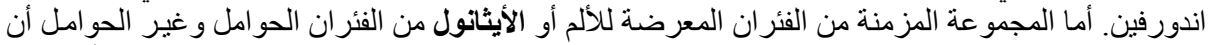

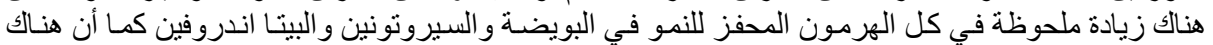

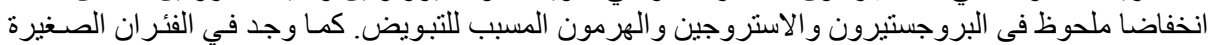

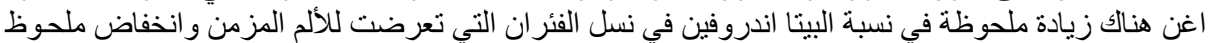
في نسل الفئران التي حقنت بادة منالأثنانول.

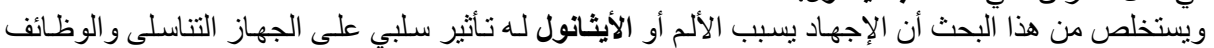

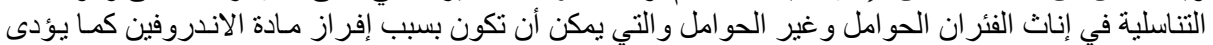

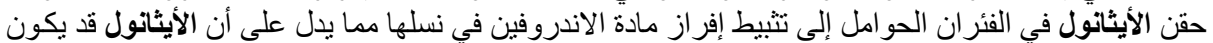
سببا في ضمور الأعصاب التي تفرز مادة الاندروفين في نسل الفئر ان المحقون فئنة الأيثانول. 